\title{
Context matters: faculty norms on binge drinking relate to binge drinking behaviour in higher education
}

\author{
Joris Van Damme ${ }^{*}$, Anne Hublet ${ }^{1}$, Bart De Clercq ${ }^{1}$, John McAlaney ${ }^{2}$, Guido Van Hal ${ }^{3}$, Johan Rosiers ${ }^{4}$, Lea Maes ${ }^{1}$, \\ Els Clays ${ }^{1}$
}

From Methods in Epidemiology Symposium

Leuven, Belgium. 17 September 2015

\section{Background}

In higher education binge drinking is an important problem. To target binge drinking in students, studying the social context of students is necessary. Faculties are social contexts in which students behave, but little is known about how faculty binge drinking norms relate to monthly binge drinking. In this study, this relationship is investigated in addition to known personal determinants.

\section{Methods}

Data were collected from 7,181 students in 22 facultylevel units, using an anonymous online survey. Multilevel analyses were used to investigate the relationship of both individual-level determinants (i.e., perceived binge drinking norms and social drinking motives) and faculty-level binge drinking norms, with monthly binge drinking.

\section{Results}

Almost two-third (62.2\%) of the sample was female and the mean age was $21.06(\mathrm{SD}=2.85)$ years. In males, significant faculty-level variance in monthly binge drinking was found. At faculty-level only faculty binge drinking norms about male students showed a positive relationship $(\mathrm{OR}=2.586 ; 95 \% \mathrm{CI}=[1.025,6.522])$. At individual level both perceived binge drinking norms about male and female students, and social drinking motives positively related to monthly binge drinking. In females no significant faculty-level variance was found. Only individual-level determinants (i.e., perceived binge drinking norms and social drinking motives) positively related to

${ }^{1}$ Ghent University, Gent, Belgium

Full list of author information is available at the end of the article monthly binge drinking. No cross-level interactions were found.

\section{Conclusion}

Faculties are especially in men relevant environmental structures and networks to take into account besides individual determinants when targeting binge drinking in higher education.

\section{Authors' details}

'Ghent University, Gent, Belgium. 'Bournemouth University, Bournemouth, United Kingdom. ${ }^{3}$ Antwerp University, Antwerp, Belgium. ${ }^{4}$ Association for Alcohol and other Drug problems, Brussels, Belgium.

Published: 17 September 2015

doi:10.1186/2049-3258-73-S1-P13

Cite this article as: Van Damme et al:: Context matters: faculty norms on binge drinking relate to binge drinking behaviour in higher education Archives of Public Health 2015 73(Suppl 1):P13.

Submit your next manuscript to BioMed Central and take full advantage of:

- Convenient online submission

- Thorough peer review

- No space constraints or color figure charges

- Immediate publication on acceptance

- Inclusion in PubMed, CAS, Scopus and Google Scholar

- Research which is freely available for redistribution

Submit your manuscript at www.biomedcentral.com/submit
() Biomed Central 